\title{
Saffron is a monomorphic species as revealed by RAPD, ISSR and microsatellite analyses
}

\author{
Angela Rubio-Moraga ${ }^{1}$, Raquel Castillo-López ${ }^{2}$, Lourdes Gómez-Gómez ${ }^{1}$ and \\ Oussama Ahrazem*1
}

\author{
Address: ${ }^{1}$ Departamento de Ciencia y Tecnología Agroforestal y Genética. ETSIA. Universidad de Castilla-La Mancha, Campus Universitario s/n, \\ Albacete, 02071. Spain and 2VITAB Laboratorios. Polígono Industrial Garysol C/Pino, parcela 53, La Gineta, 02110, Albacete. Spain \\ Email: Angela Rubio-Moraga - angela.rubio@uclm.es; Raquel Castillo-López - gerencia@vitablaboratorios.com; Lourdes Gómez- \\ Gómez - marialourdes.gomez@uclm.es; Oussama Ahrazem* - oussama.ahrazem@uclm.es \\ * Corresponding author
}

Published: 23 September 2009

BMC Research Notes 2009, 2:189 doi:10.1186/1756-0500-2-189

This article is available from: http://www.biomedcentral.com/1756-0500/2/189

(c) 2009 Rubio-Moraga et al; licensee BioMed Central Ltd.

This is an Open Access article distributed under the terms of the Creative Commons Attribution License (http://creativecommons.org/licenses/by/2.0), which permits unrestricted use, distribution, and reproduction in any medium, provided the original work is properly cited.
Received: 3 July 2009

Accepted: 23 September 2009

\begin{abstract}
Background: Saffron (Crocus sativus) is considered the world's most expensive spice. Used mainly as a colorant for foodstuffs, it is highly appreciated for its aromatic and flavouring properties. Since no molecular markers for this species have been found in the literature, the objective of this study was to determine whether phenotypical differences found in $C$. sativus were supported by molecular analyses.
\end{abstract}

Findings: Thirty primers from Operon Technologies were used in random amplified polymorphic DNA (RAPD) analysis, forty eight primers were screened using intersimple sequence repeats (ISSR) method and fifteen primers derived from a microsatellites library flanking sequences with repeat motifs were assayed in forty three isolates of $C$. sativus from eleven different countries and a C. kotschyanus isolate was used as outgroup. No polymorphic bands were detected in any of the accessions combining the different approaches used in this study.

Conclusion: According to our findings, all accessions appear identical clones, not only because morphological characters but also at a molecular level. These data strongly suggested that $C$. sativus is a monomorphic species. Thus, genome sequencing is needed to find molecular markers for saffron.

\section{Background}

The domesticated saffron (Crocus sativus) is an autumnflowering perennial plant unknown in the wild. It is a sterile triploid form, possibly of the eastern Mediterranean autumn-flowering C. cartwrightianus, which originated in Crete, or in Central Asia. Mainly used as a colorant for foodstuffs, it is characterized by a bitter taste and a haylike fragrance; due to the presence of picrocrocin and safranal. It also contains apocarotenoid compounds, which give food the yellow-orange color [1]. These traits make saffron a much-sought ingredient in many foods worldwide. Saffron was also said to have a high valued as medicinal plant, traditionally it used against cancer, depressive mood, menstruation disorders, liver disease and pain [2].

Today, saffron is cultivated from the Western Mediterranean (Spain) through Persia to India, Tibet and China. New cultivations have been created in Australia, Mexico, Argentine and New Zealand. Spain and Iran are the largest producers, together accounting for more than $80 \%$ of 
world production, which is approximately 205 tons per year [2].

The new Common Agricultural Policy of the European Union (CAP), along with increasing consumer demand for natural products of high quality, has led to resurgence in saffron culture after a long period of gradual decline and abandonment in traditional European production. Only 3,378 $\mathrm{kg}$ of saffron, with a value of approximately 4 million Euros, were produced in Spain in 2003. In spite of the reduced area dedicated to saffron cultivation, the employment generated by this sector is very high.

The planting of corms is a difficult task being planted one by one by hand. After a period of dormancy through the summer, the corms sprout in early autumn and flowers appear in mid-autumn. Flower harvest and removal of saffron stigmas are also mainly done by hand [2].

The taxonomy of Crocus is extremely complicated due to the lack of clear distinctive characters, the wide range of habitats and the heterogeneity of the morphological traits and cytological data. Phenotypical differences have been mentioned concerning the size and the number of the flowers produced by corms, although no molecular makers have been described for Crocus sativus [3].

The aim of this work was to determine whether C. sativus is a monomorphic or a polymorphic species. The different molecular approaches used were based on PCR methods such as random amplified polymorphic DNA (RAPD), intersimple sequence repeats (ISSR) and microsatellites, which have been widely used as markers [4-11].

\section{Methods}

\section{Source of experimental material}

For this study, 44 Crocus sativus isolates were included; with C. kotschyanus used as outgroup. The details of the accessions and their geographic origin are listed in Table 1. Three individuals representing each population were used. Plant tissues were independently harvested, frozen in liquid nitrogen and stored at $-80^{\circ} \mathrm{C}$ until required.

\section{DNA extraction}

DNA was extracted from 150 to $300 \mathrm{mg}$ of leaf material using a modified Doyle and Doyle method [12]. Leaf material was ground to a fine powder in liquid nitrogen and placed in a microcentrifuge tube with $2 \mathrm{~mL}$ of extraction buffer (2\% CTAB, $100 \mathrm{mM}$ Tris-HCl $\mathrm{pH} 8.0,20 \mathrm{mM}$ EDTA, $1.4 \mathrm{M} \mathrm{NaCl}$, and $0.01 \%$ proteinase $\mathrm{K}$ ) plus $40 \mu \mathrm{l}$ of 2-mercaptoethanol. Following incubation at $65^{\circ} \mathrm{C}$ for 30 min, $1.4 \mathrm{~mL}$ of chloroform:isoamyl alcohol $(24: 1)$ was added, mixed and centrifuged at $8000 \mathrm{rpm}$ for $30 \mathrm{~min}$; the supernatant was transferred to a new tube and then repeated three times. DNA was precipitated with isopropanol (2/3 volume of supernatant), then centrifuged at
Table I: Geographic origin and accessions used in this study.

\begin{tabular}{|c|c|}
\hline Species & Geographic location \\
\hline Crocus sativus & Guadalajara, Spain \\
\hline Crocus sativus & Gineta, Spain \\
\hline Crocus sativus & El Bonillo, Spain \\
\hline Crocus sativus & Zulema, Spain \\
\hline Crocus sativus & Tobarra, Spain \\
\hline Crocus sativus & Motilla del Palancar, Spain \\
\hline Crocus sativus & Nava de Abajo, Spain \\
\hline Crocus sativus & Abengibre, Spain \\
\hline Crocus sativus & Fuentealbilla, Spain \\
\hline Crocus sativus & Cordovilla, Spain \\
\hline Crocus sativus & Lezuza, Spain \\
\hline Crocus sativus & Ledaña, Spain \\
\hline Crocus sativus & Alcala de Jucar, Spain \\
\hline Crocus sativus & Tarazona de la Mancha, Spain \\
\hline Crocus sativus & Minaya, Spain \\
\hline Crocus sativus & Munera, Spain \\
\hline Crocus sativus & Madridejos, Spain \\
\hline Crocus sativus & La Solana, Spain \\
\hline Crocus sativus & Madrigueras, Spain \\
\hline Crocus sativus & Teruel, Spain \\
\hline Crocus sativus & Pedroñeras, Spain \\
\hline Crocus sativus & North region of Torbat, Iran \\
\hline Crocus sativus & Central region of Torbat, Iran \\
\hline Crocus sativus & Central region of Torbat, Iran \\
\hline Crocus sativus & Central region of Torbat, Iran \\
\hline Crocus sativus & Central region of Torbat, Iran \\
\hline Crocus sativus & East region of Torbat, Iran \\
\hline Crocus sativus & East region of Torbat, Iran \\
\hline Crocus sativus & South east region of Torbat, Iran \\
\hline Crocus sativus & East region of Ferdows, Iran \\
\hline Crocus sativus & Italy \\
\hline Crocus sativus & Italy \\
\hline Crocus sativus & Italy \\
\hline Crocus sativus & Azerbaijan \\
\hline Crocus sativus & Azerbaijan \\
\hline Crocus sativus & UK \\
\hline Crocus sativus & UK \\
\hline Crocus sativus & Turkey \\
\hline Crocus sativus & Turkey \\
\hline Crocus sativus & Taliouine, Morroco \\
\hline Crocus sativus & Christchurch, New Zealand \\
\hline Crocus sativus & Kashmir, India \\
\hline Crocus sativus & China \\
\hline Crocus sativus & Sierre de Cordoba, Argentine \\
\hline Crocus kotschyanus & Pottertons nursery, UK \\
\hline
\end{tabular}

$8000 \mathrm{rpm}$ for $30 \mathrm{~min}$, the supernatant discarded and the pellet washed in $70 \%$ ethanol containing $10 \mathrm{mM}$ ammonium acetate for $20 \mathrm{~min}$. The pellet was dissolved in 100 $\mu \mathrm{L}$ of TE buffer (10 mM Tris-HCl pH 7.4, 1 mM EDTA) and the DNA was reprecipitated with $1 / 2$ volume of ammonium acetate $3 \mathrm{M}$ and 2.5 volumes of ethanol. After centrifuging at $8000 \mathrm{rpm}$ for $30 \mathrm{~min}$, the pellet was redissolved in TE buffer with $10 \mu \mathrm{g} / \mathrm{mL}$ RNase and incubated at $30^{\circ} \mathrm{C}$ for $30 \mathrm{~min}$. The extracted DNA was quantified with a spectrophotometer and diluted to $30 \mathrm{ng} / \mu \mathrm{L}$ in TE. The DNA was stored at $-20^{\circ} \mathrm{C}$ for further analyses. 


\section{Construction of a microsatellite library}

A library of microsatellite repeats was constructed using a procedure described by Glen and Schable [13]. Briefly, genomic DNA $(6 \mu \mathrm{g})$ was digested with restriction enzyme $R s a \mathrm{I}$ and ligated with forward and reverse SuperSNX24 adaptors (SuperSNX24 forward 5'-GTTTAAGGCCTAGCTAGCAGCAGAATC and SuperSNX24 reverse 5'-GATTCTGCTAGCTAGGCCTTAAACAAAA). The restriction-ligation product was purified (wizard SV gel, Promega), and hybridized with biotinylated di- and trinucleotide-specific oligonucleotides [(TC $)_{9^{\prime}} \quad(\mathrm{TCC})_{6}$ $(\mathrm{TGG})_{6},(\mathrm{TCT})_{10}$ ]. Hybridized fragments were captured twice with streptavidin-coated magnetic beads, and then amplified with adaptor-specific primers. The PCR products were ligated into a pGEMT (Promega, Madison, WI) and selected colonies were amplified and sequenced (ABI prism 310, Perkin Elmer). The microsatellites library was searched for sequences containing SSRs using web sat software [14], available at http://wsmartins.net/websat/

\section{DNA amplification}

\section{RAPD analysis}

15 and 30 ng of genomic DNA were amplified in a volume of $20 \mu \mathrm{l}$ containing $10 \mathrm{mM}$ Tris- $\mathrm{HCl} \mathrm{pH} 9.0,2.5 \mathrm{mM}$ $\mathrm{MgCl}_{2}, 200 \mu \mathrm{M}$ each dATP, dCTP, dGTP, dTTP, $0.4 \mu \mathrm{M}$ primer, and 1 unit of Taq DNA polymerase by means of a thermal cycler (MJ-Mini, BioRad). The cycling programme began with an initial 2 min at $94^{\circ} \mathrm{C}$ followed by 45 cycles at $94^{\circ} \mathrm{C}$ for $30 \mathrm{~s}, 38^{\circ} \mathrm{C}$ for $30 \mathrm{~s}$ and $72^{\circ} \mathrm{C}$ for 2 min plus a final 10 min at $72^{\circ} \mathrm{C}$ and storage at $4{ }^{\circ} \mathrm{C}$. The sequences of primers are shown in additional file 1.

\section{ISSR and microsatellite analyses}

15 and 30 ng of genomic DNA were amplified in a volume of $25 \mu \mathrm{l}$ containing $10 \mathrm{mM}$ Tris- $\mathrm{HCl} \mathrm{pH} 9.0,1.5 \mathrm{mM}$ $\mathrm{MgCl}_{2}, 200 \mu \mathrm{M}$ each dATP, dCTP, dGTP, dTTP, $0.4 \mu \mathrm{M}$ primer, and 1 unit of Taq DNA polymerase by means of a thermal cycler (MJ-Mini, BioRad). The cycling programme began with an initial $2 \mathrm{~min}$ at $94^{\circ} \mathrm{C}$ followed by 45 cycles at $94^{\circ} \mathrm{C}$ for $45 \mathrm{~s}, 48-62^{\circ} \mathrm{C}$ for $45 \mathrm{~s}$ and $72^{\circ} \mathrm{C}$ for $2 \mathrm{~min}$ plus a final $10 \mathrm{~min}$ at $72^{\circ} \mathrm{C}$ and storage at $4^{\circ} \mathrm{C}$. Primer sequences are shown in Additional file 2 and 3 . A negative control was added in each run to test contamination in all analyses.

Amplification products were separated by electrophoresis in $2 \%$ agarose gel containing $1 \mu \mathrm{g} / \mathrm{mL}$ ethidium bromide and TAE buffer. Alternatively, samples from microsatellites amplification were separated by electrophoresis in $4 \%$ super-fine agarose or in $6 \%$ nondenaturing polyacrylamide gel. Ten microliters of amplified DNA were mixed with $3 \mu \mathrm{l}$ sample buffer $(1.2 \mathrm{mg} / \mathrm{mL} ; 125 \mathrm{mg} / \mathrm{mL}$ Ficoll $)$ and $10 \mu \mathrm{l}$ was applied in each well of the gel. DNA molecular weight markers ( $1 \mathrm{~kb}$, Promega, Madison, WI) were then added to each gel. The gels were run at a current of $50 \mathrm{~mA}$ until the bromophenol had migrated $10 \mathrm{~cm}$ from the well. The bands were then visualized under UV light and photographed. To confirm the data obtained from microsatellites sequencing analysis were performed.

\section{Results}

gDNAs obtained from individual accessions (Spain (20), Iran (9), Italy (3), Azerbaijan (2), United Kingdom (2), Turkey (2), Morocco (1), New Zealand (1), India (1), Argentine (1) and China (1)) were used as template to perform the analyses using RAPD, ISSR and microsatellites methods.

For RAPD analysis, from the 140 primers obtained from Operon Technologies (Huntsville, Alabama) and initially tested, only 30 primers were selected for further analysis. Of the 91 primers used in a first attempt at ISSR methods; 48 primers were selected (Additional file 1 and 2). The primers chosen for both methods produced distinctly robust and reproducible bands varying in numbers. While the remainder primers failed to produce bands or the profiles obtained were different between repeated experiments. For any of the primers selected, band scores did not differ between repeated experiments or between gels. A representative result of RAPD and ISSR profiles from each geographic area is shown in Figure $1 \mathrm{~A}$ and $1 \mathrm{~B}$. All the accessions revealed the same band patterns whereas $C$. kotschyanus was different.

From the analysis of the microsatellite library. Forty seven of the 157 clones sequenced (31.3\%) contained microsatellites. Repeat motifs and expected size are shown in Additional file 2 . Sequences with repetitive motifs ranging from one to six were found. The number of repetitions ranged from 2 to 30, with di and tri-nucleotide repetitions found to be most abundant in the sequences screened. Two different di-nucleotide repetitions were found (AG/ TC) and (CT/GA), representing $22 \%$ and $27 \%$ respectively for total repetition motifs, while 7 tri-nucleotide forms were detected (TCT/AGA), (CTT/GAA), (AAG/TTC), representing $8.5 \%, 8.5 \%$ and $6.2 \%$ respectively for total repetition motifs and with a 2\% (AGC/TCG), (CAC/GTG), (CTC/GAG) and (CCT/GGA).

Primers were designed for the flanking sequences containing the repetition motif (Additional file 3). The expected size ranged from $148 \mathrm{pb}$ for CSMIC23F/R and $372 \mathrm{bp}$ for CSMIC19F/R. Fifteen of the primers designed were able to produce an amplification product, while no amplification was found when using the remaining primers. Nor did the profile patterns vary by changing the PCR conditions. The unsuccessful amplification in microsatellites analysis may be due to two possible reasons: in some cases the flanking regions were very short and we were unable to design good primers, in other cases we observed that in sequences containing large repetitive region polymerase enzymes failed to led amplification and may be explained 
A

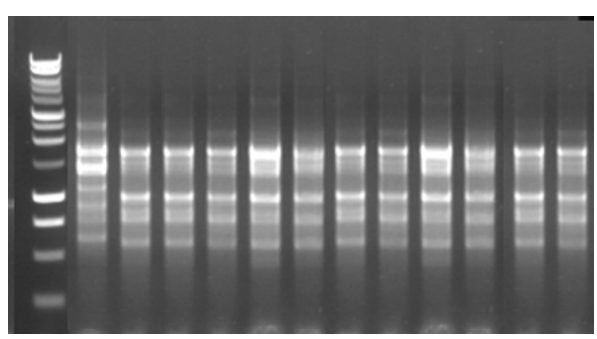

$\begin{array}{lllllllllllllllll}\text { MW } & \text { CK } & \text { SP } & \text { IR } & \text { IT } & \text { MO } & \text { CH } & \text { TR } & \text { UK } & \text { NZ } & \text { AR } & \text { AZ } & \text { IN }\end{array}$
B

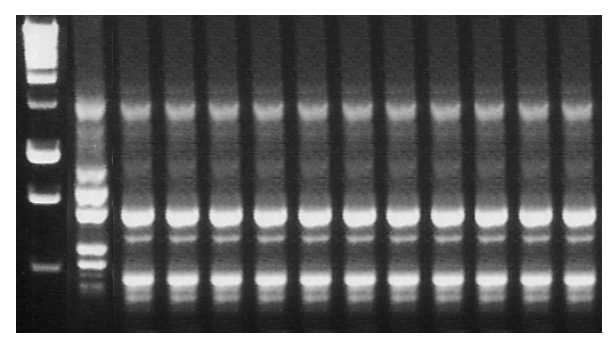

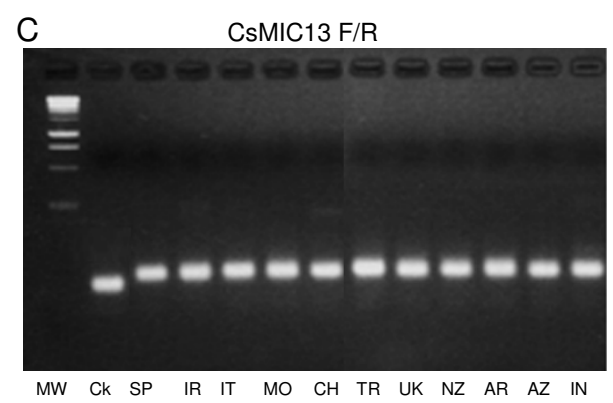

\section{Figure I}

Bands patterns of individual gDNA representing different geographic areas. A. RAPD profile using OPY 4 primer, B. ISSR profile using ISCSI7 and C. Microsatellites profiles using CsMICI $3 \mathrm{~F}$ and CSMICI3R. MW: Molecular weight (I kb, Promega); Ck: Crocus kotschyanus; SP: C. sativus from Spain; IR: C. sativus from Iran; IT: C. sativus from Italy; MO: C. sativus from Morocco; CH: C. sativus from China; TR: $C$. sativus from Turkey; UK: C. sativus from United Kingdom; NZ: $C$. sativus from New Zealand; AR: $C$. sativus from Argentine; AZ: $C$. sativus from Azerbaijan and IN: $C$. sativus from India.

by the formation of loops in the repetition regions. Bands obtained in microsatellites analysis were sequenced and no variations were observed. As happened with the RAPD and ISSR analyses, no polymorphic bands were encountered between the isolates of C. sativus whereas C. kotschyanus presented different size bands and different sequences with all the primers assayed. A representative result of microsatellites profiles from each geographic area is shown in Figure 1C.

\section{Discussion}

In this study, three different PCR-based approaches: RAPD, ISSR and microsatellites were carried out in order to determine the variability of saffron with different geographic origins ranging from New Zealand to Spain.

A total of 140, 91 and 47 primers were used in RAPD, ISSR and microsatellites analysis, respectively. Only 30, 48 and 15 primers were able to produce reproducible bands in all the different accessions of C. sativus tested. No polymorphic bands were obtained in any accessions using the three methods, which strongly suggested that C. sativus is a monomorphic species. According to the results obtained in this study, all accessions appear identical clones, not only because of morphological characters but also at the molecular level, these results agree with those obtained by Grilli-Caiola et al. using RAPD analysis [15]. In addition, the existence of differences at the phenotypic level such as size of the flowers, the shape of the tepals, differences of colour and intensity in the tepals of samples collected from different origins could not be corroborated by molecular analysis, (data not shown), thus confirming the results previously obtained by Grilli-Caiola [16] using flow citometry.

C. sativus, as a sterile plant, fails to produce viable seeds and is thus dependent on human assistance. It seems to have undergone artificial selection in the past, a practice which offers advantages in maintaining its genetic characteristics while drastically reducing the variability of plants. Observed differences in saffron quality are mainly due to the methodology followed in the processing of stigmas, independent of the species origin [17].

Perhaps by using next-generation DNA sequencing methods introduced by the 454 Company in 2003, followed by Solexa and Solid techniques from other biotechnology companies, we can look more closely at the way in which saffron has evolved. Whole genome sequences could provide us with an opportunity to study saffron population 
genetics in order to find ways to discriminate between different isolates.

\section{Conclusion}

Three PCR-based approaches: RAPD, ISSR and microsatellites failed to find polymorphisms in saffron collected from different origins. Our data suggest that saffron is a monomorphic species. To find the way to discriminate between isolates of C. sativus whole genome sequences is needed.

\section{Competing interests}

The authors declare that they have no competing interests.

\section{Authors' contributions}

ARM collected the data and participated in its analysis; RCL participated in the analysis of the data; LGG participated in the design of the study and in the analysis of the data; OA participated in the design of the study, in the analysis of the data and wrote the manuscript. All authors were involved in the interpretation of the data and approved the final manuscript.

\section{Additional material}

\section{Additional file 1}

Primers sequences used in RAPD analysis. -: negative amplification or no reproducible patterns; +: positive amplification.

Click here for file

[http://www.biomedcentral.com/content/supplementary/17560500-2-189-S1.DOC]

\section{Additional file 2}

Primers sequences and annealing temperature (Tm) used in ISSR analysis.

Click here for file

[http://www.biomedcentral.com/content/supplementary/17560500-2-189-S2.DOC]

\section{Additional file 3}

Primers sequences, repeat motif, annealing temperature (Tm) and size expected in microsatellites analysis.

Click here for file

[http://www.biomedcentral.com/content/supplementary/17560500-2-189-S3.DOC]

\section{Acknowledgements}

We thank KA Walsh (Escuela Técnica Superior de Ingenieros Agrónomos. Universidad de Castilla-La Mancha, Albacete, Spain) for language revision. This work was supported by the Spanish "Ministerio de Ciencia e Innovación" (MICINN) and by the "Junta de Comunidades de Castilla-La Mancha, Fundación de Investigación Sanitaria en C-LM" (FISCAM, PI-2007/6I). O. Ahrazem was funded by Spanish MICINN through the Ramon y Cajal Programme.

\section{References}

I. Negbi M: Saffron. Crocus sativus L Amsterdam: Harwood Academic Publ. I Overseas Publ. Ass; 1999.

2. Schmidt M, Betti G, Hensel A: Saffron in phytotherapy: Pharmacology and clinical uses. Wiener medizinische Wochenschrift 2007, I57:315-319.

3. Castillo R, Fernandez JA, Gomez-Gomez L: Implications of Carotenoid Biosynthetic Genes in Apocarotenoid Formation during the Stigma Development of Crocus sativus and Its Closer Relatives. Plant Physiology 2005, 139:674-689.

4. Chambers GK, MacAvoy ES: Microsatellites: consensus and controversy. Comparative Biochemistry and Physiology 2000, I 26:455-476.

5. Panaud $O$, Chen $X$, McCouch SR: Frequency of microsatellite sequences in rice (Oryza sativa L.). Genome 1995, 38: $1170-1176$.

6. Morgante $M$, Olivieri AM: PCR-amplified microsatellites as markers in plant genetics. Plant Journal 1993, 3:175-182.

7. Röder MS, Plaschke J, König U, Börner A, Sorrells M, Tanksley SD, Ganal MW: Abundance, variability and chromosomal location of microsatellites in wheat. Molecular and General Genetics 1995 , 246:327-333.

8. Zietkiewicz E, Rafalski A, Labuda D: Genome fingerprinting by simple sequence repeat (SSR)-anchored polymerase chain reaction amplification. Genomics |994, 20:| 76- I83.

9. Nagaraju J, Kathirvel M, Ramesh Kumar R, Siddiq EA, Hasnain SE: Genetic analysis of traditional and evolved Basmati and nonBasmati rice varieties by using fluorescence-based ISSR-PCR and SSR markers. Proceeding of the National Academy of Sciences of the United States of America 2002, 99:5836-584I.

10. Ding G, Li X, Ding X, Qian L: Genetic diversity across natural populations of Dendrobium officinale, the endangered medicinal herb endemic to China, revealed by ISSR and RAPD markers. Genetika 2009, 45:375-82.

II. Yuan XF, Dai ZH, Wang XD, Zhao B: Assessment of genetic stability in tissue-cultured products and seedlings of Saussurea involucrata by RAPD and ISSR markers. Biotechnology Letters 2009, 3 I: I279-87.

12. Doyle JJ, Doyle JL: A rapid DNA isolation procedure for small quantities of fresh leaf tissue. Phytochemical Bulletin 1987, 19:11-15.

13. Glenn TC, Schable NA: Isolating microsatellite DNA. Methods in Enzymology 2005, 395:202-222.

14. Martins WS, Lucas DCS, Neves KFS, Bertioli DJ: WebSat 2009: A Web Software for MicroSatellite Marker Development. Bioinformation 2009, 3:282-283.

15. Grilli-Caiola M, Caputo P, Zanier R: RAPD analysis in Crocus sativus L. accessions and related Crocus species. Biologia Plantarum 2004, 48:375-380.

16. Grilli-Caiola M: Saffron Reproductive Biology. Proceedings of the First Internacional Symposium on Saffron Biology and Biotechnology 2004:25-37.

17. Ordoudi E, Tsimidou M: Saffron quality: Effect of agricultural practices, processing and storage. In Production Practices and Quality Assessment of Food Crops Edited by: Dris R, Jain SM. Dordrecht The Netherlands Kluwer Academic Publishers; 2004:209-260.

Publish with Bio Med Central and every scientist can read your work free of charge

"BioMed Central will be the most significant development for disseminating the results of biomedical research in our lifetime. "

Sir Paul Nurse, Cancer Research UK

Your research papers will be:

- available free of charge to the entire biomedical community

- peer reviewed and published immediately upon acceptance

- cited in PubMed and archived on PubMed Central

- yours - you keep the copyright 